\title{
Rural Economy and Self Dependent Village in Maratha Period
}

\author{
Dr. Littan Sarkar*, \\ B-2/401 ,Kalyani, Nadia,W.B, India
}

\begin{abstract}
The paper tries to bring a relationship between the effects of Marathas in economic reforms towards rural economy and self dependent villages in our country. As we all are well aware of the gains that our country has experienced from the globalization, liberalization and privatization policies adopted by our planners. But our farming community and a majority of our rural population do not gate a single pie from those measures. This paper tries to bring about the harsh realities of our growth story in the Maratha period (1674-1761) .in this paper suitable remedial measures have been suggested and most importantly the trickle down of benefits of Maratha rural economic reforms on our agricultural and rural sectors has been elaborately deal with

Key ward; Rural, Depends, Community, Reforms ,Growth
\end{abstract}

\section{Rural Economy:}

Animal husbandry made the Maratha peasants wealthy. The production of milk in the region of southern Maharashtra, Khandesh and Berar was immense. A salient feature of the rural economy was the production of agro-manufacturers, which combined agriculture with handicrafts or cottage industries like oil pressing, hand looms textile industry corn-thrashing etc. Cottage industries were mainly dependent on the agricultural output. But some of them were totally non-agricultural. For example house hold utensils, furniture, leather work, tailoring, pottery, building industry and means of transport were also flourishing. The most important ago based industry was textile manufacture. The cotton industry helped a lot to improve the economic status of the peasants who grew cotton. The rice cultivators were also

Economically sound. The partial output of rice was exported to Bombay where the East India Company was engaged in trade. Due to the movement of the army and the irregular activity of soldiers the peasants faced lots of problem. In such events the Maratha Government always favored the peasants. For example, when the Maratha camped near kasbe Supe, the fields under cultivation were trampled upon by the soldiers resulting in damage to the crops. The Maratha administrator ordered that the peasants should be given compensation, one third of which was to be directly paid by the Government and the remaining two thirds was to be paid to the villagers by Mahipatrao Kavade.[1] When the armies of Jagdeorao Pawar Camped near Shirpur, the army stoel the crops from the nearby village. This province was under Krishna Dabhade and jagdeoraoPawar, the sardars of the peshwa. Dabhade therefore requested Chimaji Appa to warn the sardar and his army. [2] In one incident the army of Balaji Bajirao and Sadashivrao Bhau camped in the field of Govindrao Shitole Deshmukh. The soldiers consumed the crops. The Maratha Government paid an amount of rupees on hundred and fifty toward compensation for the loss.[3] These are a few examples which speak about the promptness of the Maratha Government regarding the protection of cultivators from untoward events.

\section{SELF - DEPENDENCE OF VILLAGES:}

The villages and the towns during the Maratha period were self-dependent. Elphinstone's observation in this context is important and interesting: "In whatever point of view we examine the native government in the Deccan, the first and the most important feature is the division into villages or townships. These communities contain, in miniature. All the materials of the state within themselves and are almost sufficient tot protect their members, if all other government were withdrawn".

Surendranath Sen correctly observes the democratic spirit of the Maratha village dwellers in the following words:

"When mediaeval India, distracted by selfish wars and courts intrigues, presents an unbroken array of gaudy pictures in red and black only these small villages in Maharashtra not only furnish us with instances of republican institutions, but also give evidence of the existence of democratic principles to a greater or less extent."

While examining the living standard of the $18^{\text {th }}$ century Maratha peasant's one should not fail to note how their economic life was well regulated by the spirit of social equality The Warkari sect which was Marathi Vaishnavism did establish this spirit long back in the 13th century Community feeling was always very strong in the Maratha peasants. Even the financial arrangement in rural life had republican spirit. The maintenance of the village temple was a common responsibility of the villagers. In this regard Elphinstone remarks: "The 
maintenance of the village temple; its fixed and authorized pensions, and annual charities; its ceremonies and religious festivals; its alms to beggars and entertainment to guests etc. and the fees of peons stationed in the village, entail a number of expenses on the community, which unless allowed for from the Government revenue (which is very rare) are defrayed by a tax on the village" The contemporary documents reveal that "the charges for the temple, charity and festivals were permanent and more or less constant, and were therefore raised by a permanently fixed tax called salabad' while the less constant and uncertain but none the less recurring charges were met by an extra assessment called Sadar Warid patti. In addition to these recurring expenses, there were non recurring ones, the most important of them in those insecure times being that incurred for the repair of the village wall and the purchase of forbearance of an insurgent or an enemy against whose arms the villagers were helpless. The government was sometimes ready to make some remission of revenue for the second item, but a total remission or concession even to the amount of contribution paid by the villagers, was absolutely unknown. In such cases if the amount was very heavy a public debt was contracted and gradually paid off by an annual assessment included in the Sadar-Warid Patti or mortgages or grants of lan on the part of villagers. These grants, known as Gaon Nishbat inam, were enjoyed rent free by the creditors. If small in area non rent was charged for these imams, but if big, rent was paid by the villagers in common."[4]

Though the soil of Maharashtra is not as fertile as the valley of the Ganga and the jamuna or the Narmada the economic status of the Maharashtrian peasant in the days of the Maratha rulers was certainly superior to his fatuity in other provinces. It was owing to the fact that a Maratha-Kunbi peasant was a skilled swordsman too. Almost all healthy and stout young peasants were recruited in the Maratha army. It was a salient feature of the Maratha cavalry that in the rainy season he soldiers worked as peasants on their farms and as soon as the field activities were over in the beginning of winter they prepared themselves for war expeditions to be conducted by the Maratha Sardars under the Marathas. These peasant-cum-soldiers were engaged in war expeditions till end of summer every year.

As the peasants were part time soldiers, called either Shiledar or Bargir, they earned an additional income which made their financial status more sound. This certainly helped to improve their standards of living. This life style also helped them to develop an approach of the warrior towards life. It gave them undaunted courage and fighting spirit to face day-to-day problems of life.

The small peasants who owned the land less than 10 areas or so may be regarded as rural poor peasant. This measure was also applicable to the village artisans and servants. They used to live in mud huts thatched with straw and worn fewer clothiers, possibly due to the simpler habit of the age.[5]

The village artisans and servants collectively were called twelve Balutedars.They were given their Balute,[6] the annual amount was Rs 10/- each to carpenter, leather-worker, rope-maker, and mahar.[7] Rs. 5/each to blacksmith, potter, barber and washer man: and Rs. 2.5/- to goldsmith, astrologer, Hindu temple keeper and Masjid-keeper towards the end of the 18 century.[8] It is obvious that these cash payment were very small as compared with urban wages. But it should be noted that the Balut payment was not mad to each family of Balutedars but to each Watan and they had to divide the money among themselves.[9] Moreover, it must be added that the Balute payment was not the only income for them. Each of them was entitled to a share of the offerings dedicated to village temples and also received occasional perquisites. Many of them wre granted a small plot of land by the village community as Inarn. Besides, they worked for the markets in their spare time and earned extra cash income.[10] It should be noted that about the middle of the $18^{\text {th }}$ century two goldsmiths employed in a western Deccan village are stated an emergency tax of rs. 36/-. A washer man of the same village is said to have hoarded Rs. 500/- under the floor of his house.[11]

The Mirasdars were hereditary village officers and were considered the rural rich of the time. They lived in stone houses and their women folk wore many gold and silver ornaments.

There was a custom for the private as well as government servant (slave) in Maharashtra to be paid a ser of coarse grains a day per head during the 18 the century and had a separate room too. Apart from that, the government slaves were granted a small amount of money for clothes on important festivals and were also paid pocket money of Rs. 30/- every year.[12] The prisoners who were engaged in manual labour were given ser of coarse grain a day. Axharman of the government employed at Satara was paid a set of rice a day as his wage.[13]

Wages were paid move in cash tan in-kind. For example when three tailors were employed by the Poona Government to prepare the Peshwa's robes in 1750, they were paid jointly Rs 1-2 annas per two days (i.e. 3 annas a day per head on the average). in 1765-66 the peons were employed at Nasik mint were paid Rs. 6 each per month (means 3 annas a dya). Taking into consideration the prices of foodstuff, the wage of 3 annas a day has probably, enough to maintain a small family.[14] There were great differences in the standard o living among different class both in the rural and urban areas.[15]

The peasants in Maratha state were generally a people of simple habits. Religious outlook, predominant in those days, was displayed in their life as a reflection of Warkari philosophy. Their houses were built with mud and bricks with descending roofs. Only the patils in villages had a well built house which was called 
'Wada' Rich people living in towns had big houses. The peasant's costumes also were very simple. Dhoti and bundle (shirt like clothing) were popularly put on by rich and poor peasants alike. All peasants used to cover their head with long cloth called Rumal, or feta or Safa. The Brahmin peasants put on a hat like cap called Pagdee. As regards their food habits Bhakar mad form Jawar flour and dal, onion, chillee and small quantity of oil was enough for them. They had a liking for non vegetarian food but its intake was not a regular feature the Brahmins did not eat non-veg food.

We can proudly mention here that spinning and weaving were the national industries of India. The spinning wheel and the handloom were universally in use. It is safely concluded that nearly half the adult female population of India increased the incomes of their husbands and their fathers by the profits of their own labour [16]. It was the most important industry which was suited to Indian village life. At that time, there were no great mills and factories. Each village woman purchased her cotton from the village market and sold her yarn to the village weaver. The village weaver manufactured cloth from that year and sold it to merchants and traders.[17] This was the type of life the peasants lived, it seems, during the peshwa period. The standard of living of peasants was not so high in this period but they were satisfied.

The women from the peasant class did not observe parda. They worked in fields along with the men and earned independently. Parda system was observed only among Deshmukhs and the rich class.

Wrestling was very popular in Maratha state .Every village had a gymnasium called Akhada. The instructor was known as Guruji or ustad. The trained wrestlers (pailwans) form every village displayed their skill in the wrestling competitions which very often took place in Jatra occasions on festive days.

Maharashtra during the key day of the Marathas rulers become an affluent region as wealth flew in from other provinces to Maharashtra. So even a poor peasants had a few gold and silver ornaments. Under the benevolent religious spell the peasants eagerly displayed their generosity by contributing to rising of big temples and ghats on rivers. The temples in villages became socio regions and cultural centers for the rural communities.

During the Maratha period[1674-1761] the life style in Maratha territory was static as it was elsewhere in India. New ideas. New knowledge. New concepts in various fields of life were unknown to them almost all peasants were illiterate. They did not show any curiosity about the foreigners like the Portuguese and the English. All the interest they displayed was bout the purchase of certain articles brought by the foreign trader.

Last but not the least the life of the Maratha territory peasants during the 18the century was influenced and regulated by moral and ethical values.

But during the last Peshwa, Bajirao II, the land revenue system deteriorated. Revenue farming was not unknown in maharashtra ever before 1796. But it was bajirao II, the last Peshwa who adopted it widely after 180 to ensure his revenue. The revenue farmers exacted so much constantly from eh peasants that they gave up cultivation.[18] In such conditions, it can be safely concluded that the standard of living was not satisfactory.

\section{Conclusion:}

In the Marathas period the villages were as self sufficient as they were in $17^{\text {th }}$ century. The professionals like carpenters, iron-smith edible oil pressers made the village life self sufficient. They were called Balutdars. These Balutdars received their payments in kind at the time of harvest for the services they offered to the peasants. The village despites were solved by the Patil, Kulkarni and other prestigious balutdars. In case of disputes between two villages regarding village boundaries the government settles the matters with the help of nature persons from other neighboring village. Peasants of India always depend on the monsoon. Maratha empire peasants in $18^{\text {th }}$ century were also totally dependent upon the monsoon. It was the only source of water supply to farmers. In case of heavy or scarce rainfall, the agricultural production suffered adversely. In such occurrences the Peshwa government always extended help to the cultivators of the affected region. In Peshwa Daftar we come across a number of papers which reveal the cases of reduction of land Revenue, specially granted to the peasants in trouble. In such cases concessions were given only after proper inquiry was made through authentic sources. The peasants very often claimed compensation from the government whenever they suffered losses due to the movement of the army. In cases of plundering done by the inimical troops of the neighboring kingdoms the peasants were not only granted compensation but the land revenue was also reduced. Of course, it was done only after a proper survey was conducted by government officials.

[1]. Sardesai G.S.(ed) peshwe dafter,vol VI ,P - 746

\section{Reference}

[2]. Joshi P.M (ed) Selection from the peshwe dafter,vol 17, p - 84.

[3]. Rajwade V.K. (ed),Marathyanchya Itihasachi sadhane,vol VI,p - 72

[4]. Elphinstone, Report on the territories Conquered from the Peshwe submitted to the supremeGovt. of British India. P - 19-20.

[5]. Raichaudhari Tapan and Habib Irfan (ed). Cambridge Economic History, vol I, p - 471.1984

[6]. Ibid

[7]. Dutta Romesh, The Economic History of India in the Victorian age, p. 51

[8]. Ibid

[9]. Ibid 
[10]. Raichaudhari Tapan and Habib Irfan (ed). Cambridge Economic History of India. vol I, p - 472. 1984

[11]. Parasnis B.G. Vad G.C. (ed.) Selections from the satara Raja's and Peshwa Diaries Vol - 7 letter no. 546

[12]. Parasnis B.G. Vad G.C. (ed.) Selections from the satara Raja's and Peshwa Diaries Vol - 7 letter no. 146

[13]. Sen S.N Administrative system of the Marathas. P-670.

[14]. Parasnis B.G. and Vad G.C. (ed.) Selections from the satara Raja's and Peshwa Diaries Vol - 7, letter no. 146

[15]. Kulkarni A.R. and khare G.H. (ed.), Marathyancha Itihas, P.29.5

[16]. Dutta Romesh, The Economic History of India in the Victorian Age. P. 51

[17]. Raichaudhari Tapan and Habib Irfan (ed). Cambridge Economic History of India.vol I, P-476,

[18]. Dharam Kumar (ed) Cambridge Economic History of India. Vol II, p - 182, 1984 